\title{
Photoinduced atom-transfer reactions between transition-metal centres
}

\author{
Carol Creutz, Jeong-Sup Song, and R. Morris Bullock \\ Chemistry Department, Brookhaven National Laboratory, Upton NY 11973-5000
}

\begin{abstract}
In contrast to outer-sphere electron transfer, the intrinsic barriers to redox reactions accomplished by atom-transfer processes have received little attention. We have begun a study of the self-exchange atom transfer process for both two-equivalent and one-equivalent systems. In the former studies, NMR techniques ranging from line broadening to magnetization transfer were used for $\mathrm{C}_{5} \mathrm{H}_{5}(\mathrm{CO})_{3} \mathrm{M}^{-} / \mathrm{C}_{5} \mathrm{H}_{5}(\mathrm{CO})_{3} \mathrm{M}-\mathrm{X}$ self-exchange reactions $(\mathrm{M}=\mathrm{Mo}, \mathrm{W} ; \mathrm{X}=\mathrm{Cl}, \mathrm{Br}, \mathrm{I})$. For the one-equivalent processes, we have applied isotopically labeled materials and a photochemical method to the direct determination of the self-exchange rates for $\mathrm{C}_{5} \mathrm{H}_{5}(\mathrm{CO})_{3} \mathrm{M} \cdot / \mathrm{C}_{5} \mathrm{H}_{5}(\mathrm{CO})_{3} \mathrm{M}-\mathrm{X}$ couples. The metal radicals are produced by photocleavage of metal-metal bonded dimers by visible light.
\end{abstract}

The concept of factoring the kinetic barrier to a reaction into intrinsic and thermodynamic components has proven remarkably powerful for outer-sphere electron-transfer reactions.(1) In recent years, this approach has also been applied to proton transfer, methyl $\left(\mathrm{CH}_{3}{ }^{+}\right)$transfer, and other "atom" transfer reactions. $(2,3)$ In these applications, a crucial parameter is the free-energy barrier to the selfexchange $\left(\Delta G^{\circ}=0\right)$ reaction, $\Delta G^{\ddagger}$ ex. While $\Delta G_{e x}^{\ddagger}$ values have been inferred from kinetic data for net $\left(\Delta G^{\circ} \neq 0\right)$ reactions, only rarely (with the exception of outer-sphere electron-transfer reactions) have the intrinsic barriers been evaluated by direct study of the self-exchange process. It is becoming apparent that transition-metal complexes are excellent substrates for such studies.(4-7) In this paper we describe and compare our studies of "atom transfer" self-exchange reactions of $\mathrm{Cp}(\mathrm{CO})_{3} \mathrm{M} \cdot / \mathrm{Cp}(\mathrm{CO})_{3} \mathrm{M}-\mathrm{X}$ and $\mathrm{Cp}(\mathrm{CO})_{3} \mathrm{M}-/ \mathrm{Cp}(\mathrm{CO})_{3} \mathrm{M}-\mathrm{X}$ couples.

Following Taube(8) we adopt the term "atom transfer" for reactions in which an atom originating in either the oxidizing or reducing agent is transferred to the reaction partner so that in the activated complex both oxidizing and reducing centers are attached to the atom being transferred. In this sense, "atom transfer" designates a broad reaction class and is not restricted to reactions in which a single neutral atom is transferred (for example, a hydrogen- or halogen-atom abstraction). Reactions falling within this class then include one- and two-electron inner-sphere electron-transfer reactions, halogen- and hydrogen-atom abstractions, hydride transfer reactions, and certain proton-transfer and nucleophilic substitution reactions.

Here we describe measurements of self-exchange rate constants for one-equivalent atom-transfer reactions(9) (eq 1) with $\mathrm{M}=\mathrm{W}$ or $\mathrm{Mo}$ and $\mathrm{X}=\mathrm{Cl}, \mathrm{Br}$, or $\mathrm{I}$, and compare these to the self-exchange rates of metal anions with their metal halide (7) (eq 2) and hydride complexes (eq 2, $\mathrm{X}=\mathrm{H}$ ).(4)

$$
\begin{aligned}
& \mathrm{Cp}(\mathrm{CO})_{3} \mathrm{M}^{\mathrm{I}}+\mathrm{Cp}(\mathrm{CO})_{3} \mathrm{M}^{\mathrm{II}}-\mathrm{X} \rightleftharpoons \mathrm{Cp}(\mathrm{CO})_{3} \mathrm{M}^{\mathrm{II}}-\mathrm{X}+\mathrm{Cp}(\mathrm{CO})_{3} \mathrm{M}_{\bullet} \\
& \mathrm{Cp}(\mathrm{CO})_{3} \mathrm{M}^{0-}+\mathrm{Cp}(\mathrm{CO})_{3} \mathrm{M}^{\mathrm{II}}-\mathrm{X} \rightleftharpoons \mathrm{Cp}(\mathrm{CO})_{3} \mathrm{M}^{\mathrm{II}}-\mathrm{X}+\mathrm{Cp}(\mathrm{CO})_{3} \mathrm{M}^{0-}
\end{aligned}
$$
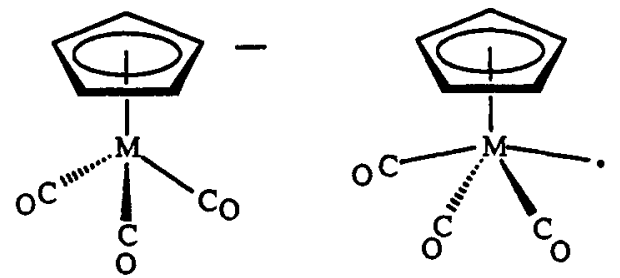

$M(0) d^{6} 18 e^{-}$

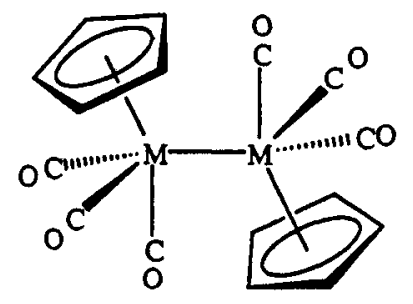

M(I) Dimer

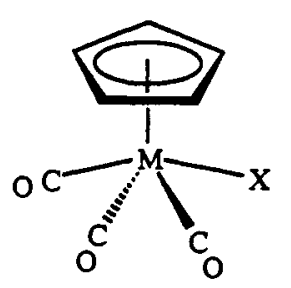

M(II) $d^{4} 18 e^{-}$ 


\section{The Reactants}

The compounds selected for our studies have structures based on either the three-legged or four-legged piano stool. Both the $\mathrm{d}^{6} \mathrm{M}(0)$ and $\mathrm{d}^{4} \mathrm{M}(\mathrm{II})$ complexes are 18-electron species, and both are extremely inert to substitution. By contrast, the $M(\mathrm{I})$ 17-electron species(10) are extremely substitution labile and, in the presence of appropriate ligands $(\mathrm{L})$, rapidly equilibrate to yield 19-electron $\mathrm{Cp}(\mathrm{CO})_{3} \mathrm{M}^{\mathrm{I}} \mathrm{L}$ adducts $(11,12)$ of moderate stability.

In the course of the two-equivalent, $\mathrm{M}-\mathrm{X} / \mathrm{M}^{-}$self-exchange (eq 2), the $\mathrm{X}$ group is transferred from the "leg" site of one reactant to that in another and only small changes in the intramolecular $\mathrm{Cp}(\mathrm{CO})_{3} \mathrm{M}$ distances and angles ensue. In the anion,(13) the OC-M-CO angles and Cp-M-CO angles are typically 86 and $128^{\circ}$, respectively; in $\mathrm{Cp}(\mathrm{CO})_{3} \mathrm{M}-\mathrm{X}$, both angles are somewhat smaller (for $\mathrm{X}=\mathrm{Cl}, 78$ and $110-125^{\circ}$, respectively).(14) The $\mathrm{Mo}-\mathrm{Cl}$ and W-Cl distances are 2.498(1) and 2.490(2) $\AA$.(14) In the course of the one-equivalent, $\mathrm{M}-\mathrm{X} / \mathrm{M} \cdot$ self-exchange, the $\mathrm{X}$ group is also transferred between the "leg" sites of the reactants. For $M=M o$ and $W$, the structures of the $M(I)$ radicals have not been characterized, but for $M=$ $\mathrm{Cr},(15-17)$ the odd electron appears sterically active (as indicated in the figure above).

\section{Methodology}

The Mo and $\mathrm{W}$ radicals are not stable, but rather dimerize (eq 3) or disproportionate under some conditions. $(10,11)$ For $M=M o$, the dimer-monomer equilibrium constant is $7.1 \times 10^{-17} \mathrm{M}$ at $25^{\circ} \mathrm{C}$ in acetonitrile.(18) For $\mathrm{M}=\mathrm{Cr}, \mathrm{K}_{\mathrm{M}}$ is much greater such that reactions of the radicals in thermal equilibrium with the dimer can be studied directly. For $\mathbf{M}=\mathbf{M o}$ and $\mathrm{W}, \mathrm{K}_{\mathbf{M}}$ is so small that photochemical methods (eq 4) are used to produce the radicals.

$$
\begin{array}{ll}
{\left[\mathrm{Cp}(\mathrm{CO})_{3} \mathrm{M}\right]_{2} \rightleftharpoons 2 \mathrm{Cp}(\mathrm{CO})_{3} \mathrm{M} \bullet} & \mathrm{K}_{\mathrm{M}} \\
{\left[\mathrm{Cp}(\mathrm{CO})_{3} \mathrm{M}\right]_{2}+\mathrm{hv} \longrightarrow 2 \mathrm{Cp}(\mathrm{CO})_{3} \mathrm{M} \bullet} & \mathrm{k}_{\mathrm{I}} \phi_{\mathrm{M}}
\end{array}
$$

The dimer absorption spectra exhibit intense $\sigma \rightarrow \sigma^{*}$ transitions at 350-400 nm and moderately intense $\mathrm{d} \pi \rightarrow \sigma^{*}$ transitions near $500 \mathrm{~nm}$.(19) Irradiation with ultraviolet or visible light induces scission of the metal-metal single bond. (At shorter wavelengths loss of $\mathrm{CO}$ also occurs,(20) but this process is not efficient with longer wavelength light.(21)) The quantum yield for radical formation $\phi_{M}$ (twice that for dimer loss $\phi_{\text {-di }}$ for eq 4$)$ is a function of irradiation wavelength $(19,22)$ and solvent viscosity $(23)$ as determined from the reaction of the radical with $\mathrm{T}-\mathrm{Y}=\mathrm{CCl}_{4}$ (eq 5) under conditions where recombination (eq 6) is negligible.

$$
\begin{array}{ll}
\mathrm{Cp}(\mathrm{CO})_{3} \mathrm{M} \bullet+\mathrm{T}-\mathrm{Y} \longrightarrow \mathrm{Cp}(\mathrm{CO})_{3} \mathrm{MY}+\mathrm{T} \bullet & k_{\mathrm{TY}} \\
2 \mathrm{Cp}(\mathrm{CO})_{3} \mathrm{M} \bullet \longrightarrow\left[\mathrm{Cp}(\mathrm{CO})_{3} \mathrm{M}\right]_{2} & \mathrm{k}_{\mathrm{di}}
\end{array}
$$

By its nature a self-exchange reaction involves no net chemical change. How then can its rate be followed? Line broadening methods (NMR and EPR) make this possible, as can Mössbauer methods under certain circumstances. Most estimates for self-exchange rates however are actually based on systems in which a small chemical change is introduced, the simplest being the use of different isotopes of a suitable element (radioactive or NMR active). In our work $(7,9)$ we have used isotopic substitution of the protons of the $\mathrm{C}_{5} \mathrm{H}_{5}$ cyclopentadienide ring. To study the metal radical reactions, perprotio $\left(\mathrm{Cp}^{\mathrm{H}}\right)$ metal dimer is irradiated in the presence of the exchange reactant containing $C_{5} D_{5}\left(C_{p} D_{M}(C O)_{3} X\right)$. The chemical shift of the $\mathrm{Cp}$ protons differs for the dimer and halogen, etc. complexes. Thus the concentrations of $\mathrm{Cp}^{\mathrm{H}}(\mathrm{CO})_{3} \mathrm{MX}$ and $\left[\mathrm{Cp}^{\mathrm{H}}(\mathrm{CO})_{3} \mathrm{M}\right]_{2}$ can be determined from ${ }^{1} \mathrm{H}$ NMR analyses of the solutions.

$$
\mathrm{Cp}^{\mathrm{H}}(\mathrm{CO})_{3} \mathrm{M} \bullet+\mathrm{Cp}^{\mathrm{D}}(\mathrm{CO})_{3} \mathrm{M}-\mathrm{X} \longrightarrow \mathrm{Cp}^{\mathrm{H}}(\mathrm{CO})_{3} \mathrm{M}-\mathrm{X}+\mathrm{Cp}^{\mathrm{D}}(\mathrm{CO})_{3} \mathrm{M} \bullet \quad \mathrm{k}_{\mathrm{ex}}
$$

Data pertinent to the photochemical experiments are given in Table 1.

The NMR data provide a measure of relative yields or rates. There are two approaches to the evaluation of the absolute rate constants. Pairs of trapping agents (for example $\mathrm{CCl}_{4}$ and $\mathrm{CBr}_{4}$ ) can be used at known concentrations. The yields of products $\left(\mathrm{Cp}^{\mathrm{H}}(\mathrm{CO})_{3} \mathrm{MCl}\right.$ and $\left.\mathrm{Cp}^{\mathrm{H}}(\mathrm{CO})_{3} \mathrm{MBr}\right)$ are used to evaluate the ratio of the rate constants $\mathrm{kCCl}_{4} / \mathrm{kCBr}_{4}$. Absolute rate constants can be evaluated if one of the rate constants in the set is known independently from transient absorption studies. The second approach uses knowledge of the rate of radical dimerization (eq 6), which requires evaluation of the radical concentration as given in the next section. 
TABLE 1. Visible Absorption Bands $\left(\mathrm{CH}_{3} \mathrm{CN}\right)$ and Cyclopentadienide ${ }^{1} \mathrm{H}$ NMR Chemical Shifts $\left(\mathrm{CD}_{3} \mathrm{CN}\right)$ of $\mathrm{Cp}(\mathrm{CO})_{3} \mathrm{MX}$ and $\left[\mathrm{Cp}(\mathrm{CO})_{3} \mathrm{M}_{2}\right.$

\begin{tabular}{llll}
\hline Complex & $\begin{array}{l}\lambda_{\max }(\mathrm{nm}) \text { and } \\
\varepsilon\left(\mathrm{M}^{-1} \mathrm{~cm}^{-1}\right)\end{array}$ & $\begin{array}{l}\varepsilon\left(\mathrm{M}^{-1} \mathrm{~cm}^{-1}\right) \text { at } \\
\lambda=578 \mathrm{~nm}\end{array}$ & $\delta\left(\mathrm{CD}_{3} \mathrm{CN}\right)$ \\
\hline $\mathrm{Cp}(\mathrm{CO})_{3} \mathrm{~W}-\mathrm{Cl}$ & $460\left(7.3 \times 10^{2}\right)$ & 19 & 5.85 \\
$\mathrm{Cp}(\mathrm{CO})_{3} \mathrm{~W}-\mathrm{Br}$ & $462\left(5.1 \times 10^{2}\right)$ & 45 & 5.84 \\
$\mathrm{Cp}(\mathrm{CO})_{3} \mathrm{WI}$ & $468\left(7.4 \times 10^{2}\right)$ & 26 & 5.82 \\
{$\left[\mathrm{Cp}(\mathrm{CO})_{3} \mathrm{~W}\right]_{2}$} & $490\left(2.2 \times 10^{3}\right)$ & $3.0 \times 10^{2}$ & $5.44,5.40$ \\
\hline $\mathrm{Cp}(\mathrm{CO})_{3} \mathrm{Mo}-\mathrm{Cl}$ & $472\left(7.2 \times 10^{2}\right)$ & 46 & 5.73 \\
$\mathrm{Cp}(\mathrm{CO})_{3} \mathrm{MO}-\mathrm{Br}$ & $478\left(4.1 \times 10^{2}\right)$ & 26 & 5.72 \\
$\mathrm{Cp}(\mathrm{CO})_{3} \mathrm{MO}-\mathrm{I}$ & $486\left(4.9 \times 10^{2}\right)$ & 60 & 5.71 \\
{$\left[\mathrm{Cp}(\mathrm{CO})_{3} \mathrm{Mo}\right]_{2}$} & $502\left(1.7 \times 10^{3}\right)$ & $3.6 \times 10^{2}$ & $5.47,5.36$ \\
\hline
\end{tabular}

\section{Kinetics scheme}

Irradiation of the dimer (eq 4) yields metal radicals. $\mathrm{k}_{\mathrm{I}}$ is the dimer excitation rate: the number of photons incident upon the solution per second, divided by the volume of the solution irradiated, corrected by Beer's law for the fraction of the light not absorbed by the dimer. $\mathrm{k}_{\mathrm{I}} \phi_{\mathrm{M}}$ is the metal-radical formation rate. Selfexchange (eq 1) between the metal radical " $M \cdot$ "and the halide " $M$ '- $X$ " complex containing $\mathrm{C}_{5} \mathrm{D}_{5}$ takes place in competition with metal-radical recombination (eq 6 ) or trapping (eq 5) by $\mathrm{T}-\mathrm{Y}$, where $\mathrm{Y}$ is a halogen and $\mathrm{T}$ is the carbon-centered fragment. $\mathrm{Eq} 7$ is included for completeness. (Note that in contrast to the $\mathrm{M}=\mathrm{Cr}$ systems,(24) for $\mathrm{M}=\mathrm{W}$ and $\mathrm{Mo}, \mathrm{Cp}(\mathrm{CO})_{3} \mathrm{M}-\mathrm{T}$ does not form at a significant rate.(25))

$$
\text { 2T. } \rightarrow \text { T-T }
$$

1. We first consider the $\mathrm{T}-\mathrm{Y}=\mathrm{CCl}_{4}$ trapping experiment (competition between eq 5 and 6 , with eq 1 omitted) and apply the steady-state approximation to the metal-radical concentration:

$$
\begin{aligned}
& \mathrm{d}\left[\mathrm{M}_{2}\right] / \mathrm{dt}=-\mathrm{k}_{\mathrm{I}} \phi_{\mathrm{M}} / 2+\mathrm{k}_{\mathrm{dil}}[\mathrm{M} \cdot]^{2} \\
& \mathrm{~d}[\mathrm{M}-\mathrm{Y}] / \mathrm{dt}=\mathrm{k}_{\mathrm{TY}}[\mathrm{T}-\mathrm{Y}][\mathrm{M} \bullet] \\
& -\mathrm{d}[\mathrm{M} \cdot] / \mathrm{dt}=2 \mathrm{~d}\left[\mathrm{M}_{2}\right] / \mathrm{dt}+\mathrm{d}[\mathrm{M}-\mathrm{Y}] / \mathrm{dt}=0
\end{aligned}
$$

Solving the resulting quadratic equation in $[\mathrm{M} \bullet]$ and taking the positive root gives eq 8 :

$[\mathrm{M} \cdot]_{\mathrm{ss}}=\left(-\mathrm{k}_{\mathrm{TY}}[\mathrm{T}-\mathrm{Y}]+\left(\mathrm{k}_{\mathrm{TY}}[\mathrm{T}-\mathrm{Y}]^{2}+8 \mathrm{k}_{\mathrm{di}} \mathrm{k}_{\mathrm{I}} \phi_{\mathrm{M}}\right)^{1 / 2}\right) / 4 \mathrm{k}_{\mathrm{di}}$

Eq 9 defines the quantum yield for $M-Y$ formation:

$$
\phi_{M Y}=k_{T Y}[M \cdot]_{s s}[T-Y] / k_{I} \phi_{M}=k_{T Y}[M \bullet]_{s s}[T-Y] /\left(k_{d i}[M \bullet]^{2}+k_{T Y}[M \bullet]_{s s}[T-Y]\right)
$$

Substitution of eq 8 into eq 9 and rearrangement yields:

$$
\left(\phi_{M}-\phi_{M Y}\right)^{1 / 2} / \phi_{M Y}=\left(\left(2 k_{d i} k_{T Y}\right)^{1 / 2}\right)\left(k_{I}{ }^{1 / 2} /[T-Y]\right)
$$

2. When two trapping agents are added, $\mathrm{T}_{\mathrm{a}}-\mathrm{Y}_{\mathrm{a}}$ and $\mathrm{T}_{\mathrm{b}}-\mathrm{Y}_{\mathrm{b}}$ (e.g. $\mathrm{CCl}_{4}$ and $\mathrm{CH}_{2} \mathrm{I}_{2}$ ),

$$
\begin{aligned}
\mathrm{Cp}(\mathrm{CO})_{3} \mathrm{M} \bullet+\mathrm{T}_{\mathrm{a}}-\mathrm{Y}_{\mathrm{a}} \rightarrow \mathrm{Cp}(\mathrm{CO})_{3} \mathrm{M}-\mathrm{Y}_{\mathrm{a}}+\mathrm{T}_{\mathrm{a}^{\bullet}} & \mathrm{k}_{\mathrm{a}} \\
\mathrm{Cp}(\mathrm{CO})_{3} \mathrm{M} \bullet+\mathrm{T}_{\mathrm{b}}-\mathrm{Y}_{\mathrm{b}} \rightarrow \mathrm{Cp}(\mathrm{CO})_{3} \mathrm{M}-\mathrm{Y}_{\mathrm{b}}+\mathrm{T}_{\mathrm{b}} \bullet & \mathrm{k}_{\mathrm{b}} \\
\text { eq } 11 \text { obtains: } & \\
\phi_{\mathrm{MY}} / \phi_{\mathrm{M}} \mathrm{Y}_{\mathrm{b}}=\mathrm{k}_{\mathrm{a}}\left[\mathrm{T}-\mathrm{Y}_{\mathrm{a}} / \mathrm{kb}_{\mathrm{b}}\left[\mathrm{T}-\mathrm{Y}_{\mathrm{b}}\right]\right. &
\end{aligned}
$$

3. Introducing the possibility of the self-exchange eq 1 is equivalent to introducing a secondary trapping reagent. Thus

$$
\phi_{\mathrm{ex}} / \phi_{\mathrm{MY}}=\mathrm{k}_{\mathrm{ex}}\left[\mathrm{M}^{\prime}-\mathrm{X}\right] / \mathrm{k}_{\mathrm{TY}}[\mathrm{T}-\mathrm{Y}]
$$

provided that $[M-X]$ is negligible, i. e. $k_{T Y}[T-Y] \gg k_{\text {ex }}[M-X]$ (that the extent of exchange is small).

\section{Details of Experimental Work and Data Treatment}

The metal complexes were prepared by standard methods cited previously(7) starting with $\mathrm{C}_{5} \mathrm{D}_{6}(26)$ instead of $\mathrm{C}_{5} \mathrm{H}_{6}$ in the preparation of $\mathrm{Cp}^{\mathrm{D}}(\mathrm{CO})_{3} \mathrm{MX}$. $\mathrm{CCl}_{4}$ was dried over $\mathrm{P}_{2} \mathrm{O}_{5}$, fractionally distilled, and stored in the dark under argon. $\mathrm{CBr}_{4}$ was sublimed at $70^{\circ} \mathrm{C}$ and stored in the dark under argon. $\mathrm{CH}_{2} \mathrm{I}_{2}$ was dried over $\mathrm{MgSO}_{4}$, fractionally distilled, and stored over $\mathrm{Cu}$ wire in the dark at $4{ }^{\circ} \mathrm{C}$. $\mathrm{CD}_{3} \mathrm{CN}$ was vacuum transferred from $\mathrm{CaH}_{2}$. 
Photolysis samples were prepared in a Vacuum Atmospheres glove box under argon in dim light and protected from the light except during the 578-nm irradiations. Stock solutions prepared from solid complex and solvent were mixed in $10 \mathrm{~mm}$ (O.D.)-NMR tubes (Wilmad) equipped with J. Young teflon valves, or $1-\mathrm{cm}$ spectrophotometer cells (for the reactions of the metal dimers with $\mathrm{CCl}_{4}$ ) to give a final solution volume of $3 \mathrm{~mL}$.

The metal radicals were generated by $578-\mathrm{nm}$ irradiation of $\mathrm{CD}_{3} \mathrm{CN}$ solutions of the appropriate $\left[\mathrm{Cp}{ }^{\mathrm{H}}(\mathrm{CO})_{3} \mathrm{M}\right]_{2}$. The photolysis train consisted of a Photon Technology International $100 \mathrm{~W} \mathrm{Hg}-\mathrm{Xe}$ lamp and monochromator (16-nm band pass), IR and UV filters, and, for intensity variations, neutral density filter(s). The photolysis cell was housed in a water-jacketed holder maintained at $25^{\circ} \mathrm{C}$. Irradiation times (10 to $120 \mathrm{~s}$ ) were controlled with an electronically actuated shutter (Ealing). The relative lamp intensity was measured before and after each run with a thermopile (Eppley Labs) and the absolute intensity (in both cuvette and NMR tube) was determined by Reineckate actinometry.(27) The beam cross-section, imaged with photosensitive paper, is a rectangle of dimensions 3 (horizontal) $\times 8$ (vertical) $\mathrm{mm}$. The NMR tube inner diameter was $0.91 \mathrm{~cm}$. Thus the irradiated volume is $0.24 \mathrm{~mL}$ for the spectrophotometer cell and $-0.22 \mathrm{~mL}$ for the NMR tube. The excitation rate in the irradiated volume ranged from $(0.02$ to 2$) \times 10^{-4}$ einstein $\mathrm{L}^{-1} \mathrm{~s}^{-1}$. The limiting radical quantum yields for chlorine transfer from $\mathrm{CCl}_{4}$ to the metal radicals were determined with $0.5 \times 10^{-3} \mathrm{M}$ dimer in 1 -cm cells by UV-vis spectroscopy.(22) $\left(\Delta \varepsilon_{486}=1.33 \times 10^{3}\right.$ $\mathrm{M}^{-1} \mathrm{~cm}^{-1}$ per dimer). The other rate constants were determined by competition studies $\left(1 \times 10^{-3} \mathrm{M}\right.$ dimer), with ${ }^{1} \mathrm{H}$ NMR analysis of the product distributions. These solutions contained bibenzyl as internal integration standard. For each system a number of preliminary experiments were conducted in order to optimize the conditions. Data reported here were obtained for mixtures (see Fig. 1) in which the rates of production of the two products were about equal (to minimize errors in the integration); data were collected to $\leq 10 \%$ dimer photolysis.

The highest value of $[\mathrm{M} \bullet]_{s s}\left(=\left(\mathrm{k}_{\mathrm{I}} \phi_{\mathrm{M}} / 2 \mathrm{k}_{\mathrm{di}}\right)^{1 / 2}\right.$ when $\left.[\mathrm{T}-\mathrm{Y}]=0\right)$ is $10^{-7} \mathrm{M}$ at the highest excitation rates used, $2 \times 10^{-4}$ einstein $\mathrm{L}^{-1} \mathrm{~s}^{-1}$. With high $\mathrm{T}-\mathrm{Y}$ concentrations, the radical steady-state concentration and lifetime $\left(1 / \mathrm{k}_{\mathrm{TY}}[\mathrm{T}-\mathrm{Y}]\right)$ are greatly reduced.

\section{RESULTS OF COMPETITION STUDIES}

A chemical competition experiment is illustrated in Fig. 1, and Fig. 2 illustrates the light intensitydependent "competition" introduced by radical recombination eq 6 . The competition results are summarized in Table 2.

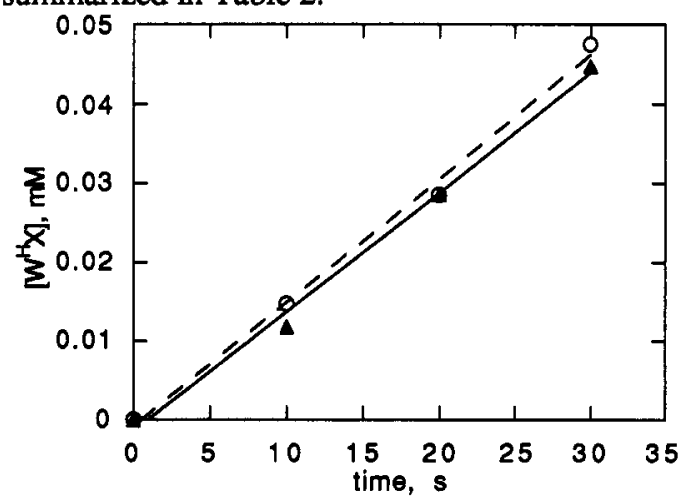

Fig. 1 Irradiation of $\left[\mathrm{Cp}^{\mathrm{H}}(\mathrm{CO})_{3} \mathrm{~W}\right]_{2}$ in the presence of $3.3 \mathrm{mM} \mathrm{CBr}_{4}$ and $0.41 \mathrm{M} \mathrm{CH}_{2} \mathrm{I}_{2}$. The ratio of the rates of formation of $\mathrm{X}=\mathrm{Br}$ (O) to $\mathrm{X}=\mathrm{I}(\boldsymbol{\Delta})$ leads to the ratio $\mathrm{kWBr} / \mathrm{kWI}=$ 137.

Earlier, to place the competition results on an absolute basis, we used $\mathrm{k}_{\mathrm{TY}}=1.2 \times 10^{4} \mathrm{M}^{-1} \mathrm{~s}^{-1}$ for the $\mathrm{W} / \mathrm{CCl}_{4}$ reaction(9). The rate constant was obtained from a light intensity dependence study and will be reevaluated below. Since publication of our report,(9) an extensive flash-photolysis study of $\mathrm{Cp}(\mathrm{CO})_{3} \mathrm{~W}$. abstraction rate constants has appeared and $\mathrm{kTY}_{\mathrm{TY}}$ values for trapping agents were given.(25) For $\mathrm{CCl}_{4}$, 
TABLE 2. Results of Competition Studies in $\mathrm{CD}_{3} \mathrm{CN}$ at $25^{\circ} \mathrm{C} .{ }^{\mathrm{a}}$

\begin{tabular}{|c|c|c|c|c|c|}
\hline \multicolumn{3}{|c|}{$\mathrm{Cp}(\mathrm{CO})_{3} \mathrm{~W} \cdot$ Reactions } & \multicolumn{3}{|c|}{$\mathrm{Cp}(\mathrm{CO})_{3} \mathrm{Mo} \cdot$ Reactions } \\
\hline $\begin{array}{l}{\left[\mathrm{CBr}_{4}\right] /\left[\mathrm{W}^{\mathrm{D}}\right]} \\
1.67 / 2.0 \\
1.67 / 1.0 \\
3.33 / 2.0 \\
1.0 / 1.0\end{array}$ & $\begin{array}{l}\text { RatewBr } \\
15.7 \\
18.6 \\
28.3 \\
13.6\end{array}$ & $\begin{array}{l}\text { kWBr/kwI } \\
1.16 \\
1.48 \\
1.24 \\
1.97\end{array}$ & $\begin{array}{l}\left.\left[\mathrm{CBr}_{4}\right] / \mathrm{Mo}^{\mathrm{D}}\right] \\
1.67 / 1.0 \\
3.33 / 1.0\end{array}$ & $\begin{array}{l}\text { RatewBr } \\
26.4 \\
31.1\end{array}$ & $\begin{array}{l}\text { kWBd } / k w I \\
0.68 \\
0.52\end{array}$ \\
\hline $\begin{array}{l}{\left[\mathrm{CBr}_{4}\right] /\left[\mathrm{CH}_{2} \mathrm{I}_{2}\right]} \\
1.67 / 207 \\
3.33 / 414\end{array}$ & $\begin{array}{l}\text { RatewBr } \\
16.6 \\
17.5\end{array}$ & $\begin{array}{l}\text { kwBr } / k w 1 \\
151 \\
137\end{array}$ & $\begin{array}{l}{\left[\mathrm{CBr}_{4}\right] /\left[\mathrm{CH}_{2} \mathrm{I}_{2}\right]} \\
3.33 / 414 \\
3.33 / 621\end{array}$ & $\begin{array}{l}\text { RateMoBr } \\
36.3 \\
36.0\end{array}$ & $\begin{array}{l}\mathbf{k}_{\mathrm{MoB} d} / \mathrm{k}_{\mathrm{MoI}} \\
241 \\
288\end{array}$ \\
\hline $\begin{array}{l}{\left[\mathrm{W}^{\mathrm{Br}}\right] /\left[\mathrm{CH}_{2} \mathrm{I}_{2}\right]} \\
5.0 / 12.42 \\
5.0 / 20.69 \\
5.0 / 28.96 \\
1.5 / 2.07 \\
1.0 / 2.07\end{array}$ & $\begin{array}{l}\text { RateWBr } \\
11.5 \\
10.2 \\
8.39 \\
52.3 \\
38.9\end{array}$ & $\begin{array}{l}\text { kwBr } / \mathrm{kWI} \\
1.45 \\
1.72 \\
1.83 \\
1.37 \mathrm{~b} \\
1.38 \mathrm{~b}\end{array}$ & $\begin{array}{l}{\left[\mathrm{Mo}{ }^{\mathrm{Br}}\right] /\left[\mathrm{CH}_{2} \mathrm{I}_{2}\right]} \\
3.0 / 8.28 \\
3.0 / 16.6 \\
\\
{\left[\mathrm{Mo}^{\mathrm{D}} \mathrm{Cl}\right] /\left[\mathrm{CH}_{2} \mathrm{I}_{2}\right]} \\
4.0 / 4.14 \\
4.0 / 6.21\end{array}$ & $\begin{array}{l}\text { Rate MoBr } \\
50.6 \\
40.1 \\
\\
\text { Rate }_{\mathrm{MoCl}} \\
21.7 \\
23.0\end{array}$ & $\begin{array}{l}\mathrm{k}_{\mathrm{MoBr}} / \mathrm{kWI} \\
13.7 \\
14.5 \\
\mathrm{k}_{\mathrm{MOC}} / \mathrm{k}_{\mathrm{MoI}} \\
1.11 \\
1.24\end{array}$ \\
\hline $\begin{array}{l}{\left[\mathrm{WD}^{\mathrm{D}}\right] /\left[\mathrm{CH}_{2} \mathrm{I}_{2}\right]} \\
8.0 / 4.14 \\
8.0 / 8.28 \\
5.0 / 1.04 \\
8.5 / 2.07\end{array}$ & $\begin{array}{l}\text { Ratewcl } \\
6.26 \\
2.68 \\
25.4 \\
22.8\end{array}$ & $\begin{array}{l}\mathrm{kwc} / \mathrm{kwI} \\
0.109 \\
0.092 \\
0.092^{\mathrm{b}} \\
0.087^{\mathrm{b}}\end{array}$ & $\begin{array}{l}4.0 / 8.28 \\
1.0 / 2.07 \\
1.5 / 2.07 \\
1.5 / 2.07\end{array}$ & $\begin{array}{l}23.9 \\
55.6 \\
71.0 \\
64.2\end{array}$ & $\begin{array}{l}1.24 \\
1.71 \\
1.59 \mathrm{~b} \\
1.21 \mathrm{~b} \\
1.32 \mathrm{~b}\end{array}$ \\
\hline $\begin{array}{l}\left.\left[\mathrm{CCl}_{4}\right] / / \mathrm{CH}_{2} \mathrm{I}_{2}\right] \\
346 / 2.07 \\
432 / 2.07\end{array}$ & $\begin{array}{l}\text { RatewCl } \\
44.3 \\
45.1\end{array}$ & $\begin{array}{l}\mathrm{kwc} / \mathrm{kwI} \\
4.47 \times 10^{-3 b} \\
4.28 \times 10^{-3 b}\end{array}$ & $\begin{array}{l}{\left[\mathrm{CCl}_{4}\right] /\left[\mathrm{CH}_{2} \mathrm{I}_{2}\right]} \\
173 / 2.07 \\
259 / 2.07 \\
173 / 3.1 \\
\end{array}$ & $\begin{array}{l}\text { Rate }_{\mathrm{MoCl}} \\
51.7 \\
101 \\
60.2 \\
\end{array}$ & $\begin{array}{l}\mathrm{k}_{\mathrm{MoC}} / \mathrm{k}_{\mathrm{MoI}} \\
0.0142 \\
0.0135 \\
0.0122 \\
\end{array}$ \\
\hline
\end{tabular}

aThe far left column gives the scavengers used and (next lines) their concentrations (mM). Following the concentration information are the rate ( $\mathrm{mM} \mathrm{s}^{-1}$ per $3 \mathrm{~mL}$ cell volume) for the first scavenger listed and (third column) the ratio of rate constants for the two scavengers. Unless otherwise noted, the excitation intensity $\mathrm{I}_{\mathrm{a}}$ was $3 \times 10^{-8}$ einstein $\mathrm{s}^{-1}$. $\mathrm{bI}_{\mathrm{a}}=20 \times 10^{-8}$ einstein $\mathrm{s}^{-1}$.

$\mathrm{CH}_{2} \mathrm{I}_{2}$, and $\mathrm{CBr}_{4}$, the values $\left(2.9 \times 10^{4}, 9.8 \times 10^{6}\right.$, and $\left.1.3 \times 10^{9} \mathrm{M}^{-1} \mathrm{~s}^{-1}\right)$ were greater than ours $\left(1.2 \times 10^{4}\right.$, $2.8 \times 10^{6}$, and $3.9 \times 10^{8} \mathrm{M}^{-1} \mathrm{~s}^{-1}$, respectively) by a mean factor of 3.04 . Because of the higher accuracy of the flash-photolysis data, this mean is used to re-evaluate the self-exchange rate constants. Thus $\mathrm{k}_{\mathrm{TY}}=$ $3.65 \times 10^{4} \mathrm{M}^{-1} \mathrm{~s}^{-1}$ for $\mathrm{CCl}_{4}$ is used with the ratios in Table 2 to obtain the $\mathrm{Cp}(\mathrm{CO})_{3} \mathrm{~W} \cdot\left(\phi_{\mathrm{M}}=1.0\right)$ data in Table 3. For $\mathrm{Cp}(\mathrm{CO})_{3} \mathrm{Mo} \cdot(\phi \mathrm{M}=1.6), \mathrm{k}_{\mathrm{TY}}=6.0 \times 10^{6} \mathrm{M}^{-1} \mathrm{~s}^{-1}$ for $\mathrm{T}-\mathrm{Y}=\mathrm{CH}_{2} \mathrm{I}_{2}$ is similarly used to normalize the data in Table 2.
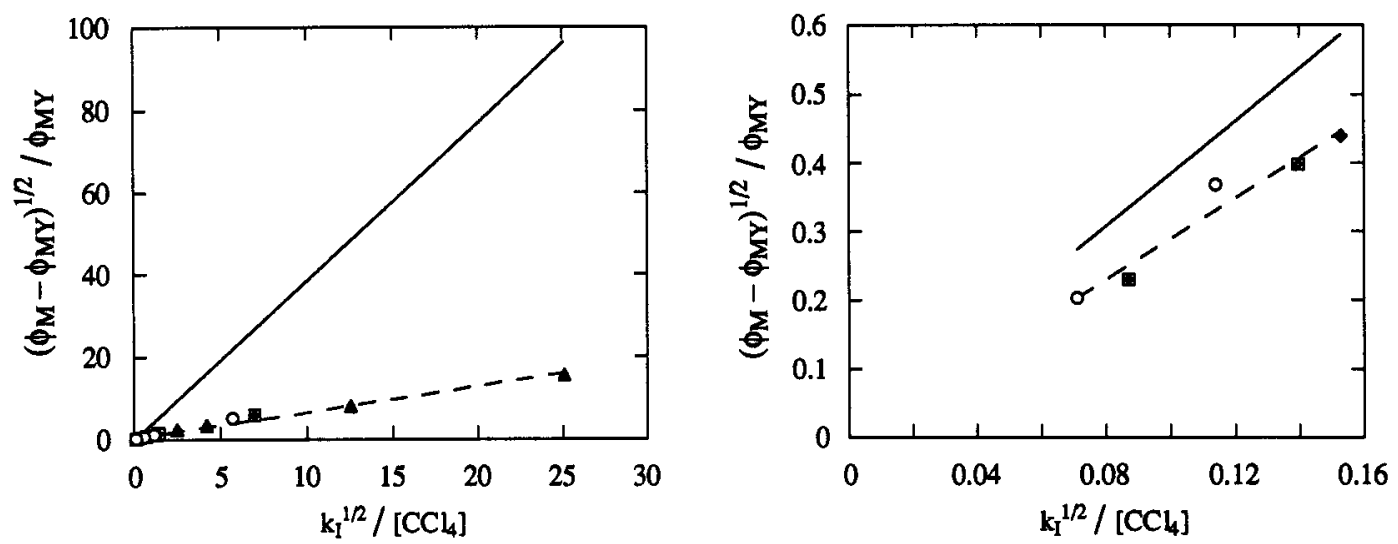

Fig. 3 and 4. Left: all 18 data points are shown; they were obtained at $\left[\mathrm{CCl}_{4}\right] 0.5$ to $80 \mathrm{mM}$ and excitation rates of $1.57 \times 10^{-4}(\Delta), 1.48 \times 10^{-4}(\diamond), 0.48 \times 10^{-4}($ ( $)$ and $0.33 \times 10^{-4}(0)$ einstein/L-s. The solid is line calculated for eq 10 with literature(25) rate constants (slope 3.84, intercept 0 ); the broken line is the fit to the experimental data (slope 0.62 , intercept $0.58, \mathrm{R}=0.99$ ). At the right, only the region near the origin is shown (slope 3.00, intercept $0, R=0.98$ ). 


\section{Light Intensity Dependence}

The values we reported earlier were based on rate constants for the $\mathrm{Cp}(\mathrm{CO})_{3} \mathrm{~W} \cdot / \mathrm{CCl}_{4}$ reaction determined from the light intensity dependence. These data were reexamined in an effort to determine the source of the disagreement. Data are shown in Figs. 3 and 4, in both of which, the solid line is calculated from eq 12 with $\mathrm{k}_{\mathrm{di}}=6.2 \times 10^{9}$ and $\mathrm{k}_{\mathrm{TY}}\left(\mathrm{CCl}_{4}\right)=2.9 \times 10^{4} \mathrm{M}^{-1} \mathrm{~s}^{-1}$. The calculated line fits the data rather well near the origin (Fig. 4), where $\left[\mathrm{CCl}_{4}\right] \geq 0.05 \mathrm{M}, \mathrm{k}_{\mathrm{TY}}\left[\mathrm{CCl}_{4}\right] \geq 1.5 \times 10^{3} \mathrm{~s}^{-1}$. Possibly our failure to include other radical reactions $(25)$ such as eq $13-14\left(\mathrm{~T}^{\circ}=\mathrm{Cl}_{3} \mathrm{C} \bullet\right)$ is responsible for the breakdown in the model at low [T-Y]. However, no products suggestive of such side reactions were noted.

$$
\begin{aligned}
& \mathrm{Cp}(\mathrm{CO})_{3} \mathrm{M} \bullet+\mathrm{T} \cdot \longrightarrow \mathrm{Cp}(\mathrm{CO})_{3} \mathrm{M}-\mathrm{T} \\
& {\left[\mathrm{Cp}(\mathrm{CO})_{3} \mathrm{M}\right]_{2}+\mathrm{T} \cdot \longrightarrow \mathrm{T}^{+}+\mathrm{Cp}(\mathrm{CO})_{3} \mathrm{M}^{-}+\mathrm{Cp}(\mathrm{CO})_{3} \mathrm{M} \bullet}
\end{aligned}
$$

\section{REACTIVITY OF THE RADICALS}

The data reanalysis carried out here (Table 3) only reinforces the earlier conclusion that the radicals exhibit remarkably small barriers to atom transfer. Similar conclusions emerge from analyses of data for net halogen transfer reactions, as well:(28) For $(\mathrm{CO})_{4} \mathrm{LRe}$ reactions the roles of steric and electronic factors on the net and intrinsic free-energy barriers have been probed for a wide variation of the ligand $L$ and "intrinsic" barriers (corrected for steric effects) of $5-8 \mathrm{kcal} / \mathrm{mol}$ were inferred. The lower limit inferred for the electron transfer self-exchange between $\mathrm{Cp}(\mathrm{CO})_{3} \mathrm{~W} \cdot$ and $\mathrm{Cp}^{\mathrm{D}}(\mathrm{CO})_{3} \mathrm{~W}^{-}\left(\geq 1 \times 10^{6} \mathrm{M}^{-1} \mathrm{~s}^{-1}\right)$ is in agreement with estimates, $3 \times 10^{7}$ and $5 \times 10^{6} \mathrm{M}^{-1} \mathrm{~s}^{-1}$ obtained from the rate constants for oxidation of the radical and the Marcus cross-relation.(29) The $\mathrm{H}$ transfer self-exchange rate constant estimated here is 7-8 orders of magnitude greater than reported for the sterically hindered $\mathrm{Tp}^{*}(\mathrm{CO})_{3} \mathrm{Mo}-\mathrm{H}\left(\mathrm{Tp}^{*}=\right.$ hydrido

\begin{tabular}{|c|c|c|}
\hline Reactants & $\mathbf{M}=\mathbf{M o}$ & $M=W$ \\
\hline $\begin{array}{l}\mathrm{Cp}(\mathrm{CO})_{3} \mathrm{M} \bullet+ \\
\mathrm{Cp}^{\mathrm{D}}(\mathrm{CO})_{3} \mathrm{M}-\mathrm{Cl} \\
\mathrm{Cp} \mathrm{D}(\mathrm{CO})_{3} \mathrm{M}-\mathrm{Br} \\
\mathrm{Cp} \mathrm{D}(\mathrm{CO})_{3} \mathrm{M}-\mathrm{I} \\
\mathrm{Cp}^{\mathrm{D}}(\mathrm{CO})_{3} \mathrm{M}^{-} \\
\mathrm{Cp} \mathrm{D}(\mathrm{CO})_{3} \mathrm{M}-\mathrm{H} \\
\mathrm{Cp}^{\mathrm{D}}(\mathrm{CO})_{3} \mathrm{M}-\mathrm{CH}_{3} \\
\mathrm{CCl}_{4} \\
\mathrm{CH}_{2} \mathrm{I}_{2} \\
\mathrm{CBr}_{4}\end{array}$ & $\begin{array}{l}8.2 \times 10^{6} \\
8.5 \times 10^{7} \\
2.6 \times 10^{9}\end{array}$ & $\begin{array}{l}7.9 \times 10^{5} \\
1.3 \times 10^{7} \\
8.2 \times 10^{8} \\
21 \times 10^{6} \\
21 \times 10^{6} \\
\leq 5 \times 10^{2} \\
\left(3.7 \times 10^{4}\right) \\
8.3 \times 10^{6} \\
1.2 \times 10^{9}\end{array}$ \\
\hline $\begin{array}{l}\mathrm{Cp}(\mathrm{CO})_{3} \mathrm{M}^{-}+ \\
\mathrm{Cp}(\mathrm{CO})_{3} \mathrm{M}-\mathrm{Cl}^{\mathrm{b}} \\
\mathrm{Cp}(\mathrm{CO})_{3} \mathrm{M}-\mathrm{Br}^{\mathrm{b}} \\
\mathrm{Cp}(\mathrm{CO})_{3} \mathrm{M}-\mathrm{I}^{\mathrm{b}} \\
\mathrm{Cp}(\mathrm{CO})_{3} \mathrm{M}-\mathrm{H}^{\mathrm{c}}\end{array}$ & $\begin{array}{l}9 \times 10^{-2} \\
16 \\
1.5 \times 10^{4} \\
2.5 \times 10^{3}\end{array}$ & $\begin{array}{l}2.1 \times 10^{-3} \\
2.8 \\
4.5 \times 10^{3} \\
6.5 \times 10^{2}\end{array}$ \\
\hline
\end{tabular}
tris(3,5-dimethylpyrazolyl)borate), while the $\mathrm{M} \bullet / \mathrm{M}^{-}$electron self-exchange rates are comparable.(30).

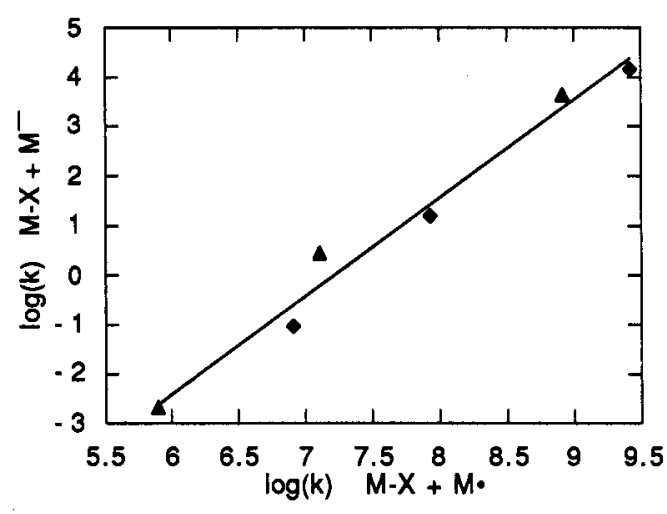

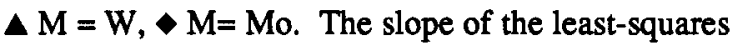
fit line is $1.99(R=0.987)$ and the intercept is -14.34 .
\end{abstract}

Fig. 5. Logarithm of the rate constant for the $\mathrm{MX} / \mathrm{M} \bullet$ vs. that for the $\mathrm{MX} / \mathrm{M}^{-}$self exchange

The $\mathrm{Cp}(\mathrm{CO})_{3} \mathrm{M} \cdot / \mathrm{Cp}(\mathrm{CO})_{3} \mathrm{M}^{-}$exchange $\left(\mathrm{k}>10^{6} \mathrm{M}^{-1} \mathrm{~s}^{-1}\right)$ presumably involves outer-sphere electron transfer and is comparable in rate to the $\mathrm{Cp}_{2} \mathrm{Co}^{0 /+}$ and $\mathrm{Cp}_{2} \mathrm{Fe}^{0 /+}$ self exchanges.(31) Rapid outersphere electron transfer for the radical/anion couple is not surprising given the small changes in bond distances and angles and the relatively small solvent reorganization barrier expected to accompany electron transfer between $\mathrm{Cp}(\mathrm{CO})_{3} \mathrm{M} \bullet$ and $\mathrm{Cp}(\mathrm{CO})_{3} \mathrm{M}^{-}$. The mechanistic classification of the $\mathrm{Cp}(\mathrm{CO})_{3} \mathrm{M} \bullet /$ $\mathrm{Cp}(\mathrm{CO})_{3} \mathrm{M}-\mathrm{X}$ self-exchanges is less straightforward. They can be regarded as inner-sphere one-electron transfer in one limit and as $\mathrm{X}$ - transfer reactions in the other. In any event, their rapid rates require a strong (electronic) coupling description when electron-transfer language is used, so that the distinction between the two limits blurs. The barriers exhibited are but a small fraction $(<15 \%)$ of the $\mathrm{Cp}(\mathrm{CO})_{3} \mathrm{M}-\mathrm{X}$ bond energies.(32) In any case, data of the type presented here begin to afford a tool for testing theoretical models for atom and group transfer reactions. $(33,34)$ 


\section{Comparison of one- and two-equivalent processes.}

In contrast to the $>5$ order of magnitude range found for the rate constants for the halide exchanges with their anions (Table 3), Atwood and colleagues have found that, in some systems ((35) and ref. therein), the variation of the rate constant with the halide is less than a factor of three (e.g. (CO) ${ }_{5} \mathrm{Re}^{-}$with $\left.\mathrm{Cp}(\mathrm{CO})_{3} \mathrm{Mo}-\mathrm{X}\right)$. Such reactions were proposed to proceed by nucleophilic attack of the metal anion at a $\mathrm{CO}$ cis to the $\mathrm{M}-\mathrm{X}$ moiety. Remarkable intramolecular halogen transfer has been observed for biruthenocene $\mathrm{Ru}^{\mathrm{II}} \mathrm{Cp}\left(\mathrm{C}_{5} \mathrm{H}_{4} \mathrm{C}_{5} \mathrm{H}_{4}\right) \mathrm{CpRu}^{\mathrm{IV}} \mathrm{X}^{+}$systems.(36)

In Fig. 5 data for eq 2, $\mathrm{X}^{+}$exchange are plotted against those for $\mathrm{X} \cdot$ exchange. Remarkably, an excellent linear correlation is observed which causes us to reexamine our original model for the $X$ selfexchanges. Earlier(7) we neglected to consider the stabilization of the radical conferred by increasing its coordination number to form the 19-electron species, estimated for halides and $M=M o$ to be 2-3 $\mathrm{kcal} / \mathrm{mol}$.(37) With such stabilization of the transition state, a pathway involving rate-determining oneelectron transfer (comproportionation), followed by very rapid transfer of the second electron, cannot be ruled out for the two-equivalent exchange.

(i) rate determining, slow, concerted one-electron transfer and bond formation

$$
\mathrm{M}^{\mathrm{II}}-\mathrm{X}+\mathrm{M}^{0-} \longrightarrow\left(\mathrm{M}^{\mathrm{I}}-\mathrm{X}-\mathrm{M}^{\mathrm{I}}\right)^{-}
$$

(ii) rapid, exergonic transfer of the second electron

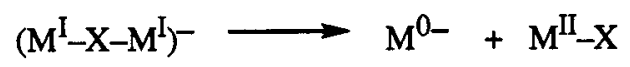

\section{Comparisons of metal- and carbon-centered systems}

In Table 4, bond dissociation energies (BDE) and self-exchange rates for the Mo radical reactions are compared with data for carbon-centered systems.(38) The latter rate data, while not self-exchange data, are for halogen abstraction reactions occurring with negligible free-energy change (eq 17). While the metal-centered reactions are slightly favored because of their lower bond energies, they may also facilitated by the long $\mathrm{M}-\mathrm{X}$ bond $(2.5 \AA$ compared to $\mathrm{C}-\mathrm{Cl} 1.77 \AA)$.

$$
\left(\mathrm{CH}_{3}\right)\left(\mathrm{CH}_{2}\right)_{3} \mathrm{X}+\left(\mathrm{CH}_{3}\right)\left(\mathrm{CH}_{2}\right)_{7^{\bullet}} \longrightarrow\left(\mathrm{CH}_{3}\right)\left(\mathrm{CH}_{2}\right)_{3}{ }^{\bullet}+\left(\mathrm{CH}_{3}\right)\left(\mathrm{CH}_{2}\right)_{7} \mathrm{X}
$$

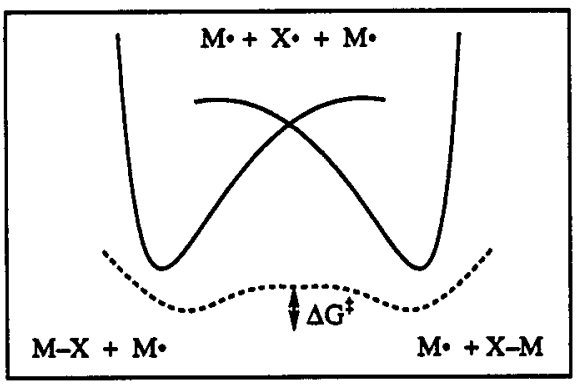

Fig. 6 Contrast between Morse curves for M-X dissociation (solid curves) and the low potential barrier (dashed curve) for atom transfer.
TABLE 4. Halogen Atom Transfer Between Alkyl Radicals and Metal Radicals

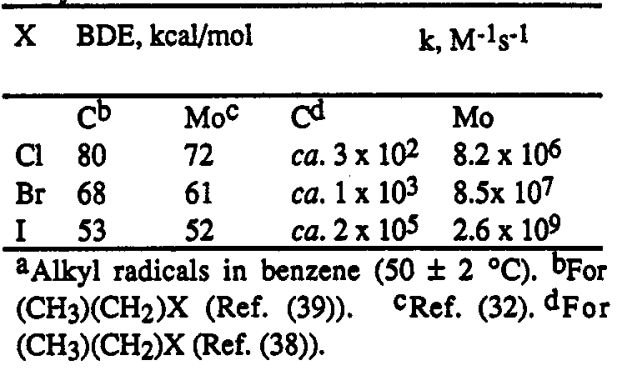

\section{CONCLUDING REMARKS}

The studies reported here reveal remarkably small barriers for halogen and hydrogen atom transfer between $\mathrm{Cp}(\mathrm{CO})_{3} \mathrm{M} \cdot / \mathrm{Cp}(\mathrm{CO})_{3} \mathrm{M}-\mathrm{X}$ couples of $\mathrm{Mo}$ and $\mathrm{W}$. Indeed for $\mathrm{X}=\mathrm{I}$, the rate constants at room temperature are within a factor of ten of the diffusion-controlled value in $\mathrm{CD}_{3} \mathrm{CN}$. The high reactivity of the metal radicals toward addition of a ligand is certainly critical to this high reactivity; the reaction barriers are $<15 \%$ of the $M-X$ bond energies, indicating that bond formation strongly stabilizes the transition states. Similarly, stabilization of radical $\mathrm{M}^{\mathrm{I}}$ oxidation state by association with an additional ligand may serve a key role in the self-exchange reactions of the $\mathrm{Cp}(\mathrm{CO})_{3} \mathrm{M}^{-} / \mathrm{Cp}(\mathrm{CO})_{3} \mathrm{M}-\mathrm{X}$ couples. Such ligand binding may sufficiently shift the thermodynamics of the systems so that the two-equivalent exchanges can proceed via sequential one-electron transfers. 


\section{ACKNOWLEDGMENT}

We thank Drs. B. S. Brunschwig, H. A. Schwarz, and N. Sutin for invaluable discussions. This research was carried out at Brookhaven National Laboratory under contract DE-AC02-76CH00016 with the U.S. Department of Energy and supported by its Division of Chemical Sciences, Office of Basic Energy Sciences.

\section{REFERENCES}

1. N. Sutin, Prog. Inorg. Chem. 30, 441-498 (1983).

2. W. J. Albery, Ann. Rev. Phys. Chem. 31, 227-263 (1980).

3. J. M. Riveros, S. M. Jose and K. Takashima, Adv. Phys. Org. Chem. 21, 197-240 (1985).

4. R. T. Edidin, J. M. Sullivan and J. R. Norton, J. Am. Chem. Soc. 109, 3945-3953 (1987).

5. T. P. Smith, D. J. Iverson, M. W. Droege, K. S. Kwan and H. Taube, Inorg. Chem. 26, 2882-2884 (1987).

6. K. Kirchner, H. W. Dodgen, S. Wherland and J. P. Hunt, Inorg. Chem. 28, 604-605 (1989).

7. C. L. Schwarz, R. M. Bullock and C. Creutz, J. Am. Chem. Soc. 113, 1225-1236 (1991).

8. H. Taube, in Mechanistic Aspects of Inorganic Reactions, D. B. Rorabacher and J. F. Endicoth, ed. ACS Symposium Series, 198, 151(1982).

9. J.-S. Song, R. M. Bullock and C. Creutz, J. Am. Chem. Soc. 113, 9862-9864 (1991).

10. W. C. Trogler, Ed., Organometallic Radical Processes, Elsevier, Amsterdam (1990).

11. A. E. Steigman and D. R. Tyler, Coord. Chem. Rev. 63, 217-240 (1985).

12. D. R. Tyler, Acc. Chem. Res. 24, 325-331 (1991).

13. M. A. Adams, K. Folting, J. C. Huffman and K. G. Caulton, Inorg. Chem. 18, 3020-3023 (1979).

14. C. Bueno and M. R. Churchill, Inorg. Chem. 20, 2197-2202 (1981).

15. S. Fortier, M. C. Baird, K. F. Preston, J. R. Morton, T. Ziegler, T. J. Jaeger, W. C. Watkins, J. H. MacNeil, K. A. Watson, K. Hensel, Y. Le Page, J.-P. Charland and A. J. Williams, J. Am. Chem. Soc. 113, 542-551 (1991).

16. R. J. Hoobler, M. A. Hutton, M. M. Dillard, M. P. Castellani, A. L. Rheingold, A. L. Rieger, P. H. Rieger, T. C. Richards and W. E. Geiger, Organometallics 12, 116-123 (1993).

17. J. H. MacNeil, A. W. Roszak, M. C. Baird, K. F. Preston and A. L. Rheingold, Organometallics 4402-4412 (1993).

18. J. R. Pugh and T. J. Meyer, J. Am. Chem. Soc. 114, 3784-3792 (1992).

19. M. S. Wrighton and D. S. Ginley, J. Am. Chem. Soc. 97, 4246-4251 (1975).

20. J. L. Hughey, IV, C. R. Bock and T. J. Meyer, J. Am. Chem. Soc. 97, 4440-4441' (1975).

21. B. A. van Vlierberge and H. B. Abrahamson, J. Photochem. Photobiol. A: Chem. 52, 68-81 (1990

22. R. M. Laine and P. C. Ford, Inorg. Chem. 16, 388-391 (1977).

23. K. J. Covert, E. F. Askew, J. Grunkemeier, T. Koenig and D. R. Tyler, J. Am. Chem. Soc. 114, 10446-10448 (1992).

24. C. A. MacConnachie, J. M. Nelson and M. C. Baird, Organometallics 11, 2521-2528 (1992).

25. S. L. Scott, J. H. Espenson and Z. Zhu, J. Am. Chem. Soc. 115, 1789-1797 (1993).

26. S. McLean, C. J. Webster and R. J. D. Rutherford, Can. J. Chem. 47, 1555-1559 (1969).

27. E. E. Wegner and A. W. Adamson, J. Am. Chem. Soc. 88, 394-404 (1966).

28. M.-G. Choi and T. L. Brown, Inorg. Chim. Acta 198-200, 823-830 (1992).

29. S. L. Scott, J. H. Espenson and W.-J. Chen, Organometallics 12, 4077-4084 (1993).

30. J. D. Protasiewicz and K. H. Theopold, J. Am. Chem. Soc. 115, 5559-5569 (1993).

31. R. M. Nielson, G. E. McManis, M. N. Goloving and M. J. Weaver, J. Phys. Chem. 92, 3441-3450 (1988).

32. S. P. Nolan, R. L. de La Vega and C. D. Hoff, J. Organomet. Chem. 315, 187-189 (1986).

33. R. A. Marcus, J. Phys. Chem. 72, $891-899$ (1968).

34. A. O. Cohen and R. A. Marcus, J. Phys. Chem. 72, $4249-4256$ (1968).

35. W. S. Striejewske, R. F. See, M. R. Churchill and J. D. Atwood, Organometallics 12, 4413-4419 (1993).

36. M. Watanabe, I. Motoyama, M. Shimoi and T. Iwamoto, Inorg. Chem. 33, 2518-2521 (1994).

37. C. E. Philbin, C. A. Granatir and D. R. Tyler, Inorg. Chem. 25, 4806-4807 (1986).

38. M. Newcomb, R. M. Sanchez and J. Kaplan, J. Am. Chem. Soc. 109, 1195-1199 (1987).

39. A. J. Gordon and R. A. Ford, The Chemist's Companion, Wiley, New York (1972). 